\title{
Socio-epidemiological characterization of human leptospirosis in the Federal District, Brazil, 2011-2015
}

\author{
Ivanildo de Oliveira Correia Santos ${ }^{[1]}$, Marina Frota de Albuquerque Landi ${ }^{[2]}$, \\ Eduardo Maurício Mendes de Lima ${ }^{[2]}$, Laurício Monteiro Cruz ${ }^{[1]}$, Maria Isabel Rao Bofill[1], \\ Divino Eterno dos Santos ${ }^{[1]}$ and Márcio Botelho de Castro ${ }^{[2]}$
}

[1]. Departamento de Vigilância Ambiental, Secretaria da Saúde, Administração do Distrito Federal, Brasília, DF, Brasil.

[2]. Faculdade de Agronomia e Veterinária, Universidade de Brasília, Brasília, DF, Brasil.

\begin{abstract}
Introduction: Human leptospirosis (HL) in the Federal District (DF), Brazil, is endemic and requires studies to characterize the socio-epidemiological profile of the vulnerable population. Methods: Seventy-nine autochthonous cases of HL between 2011-2015 were analyzed based on the databases of the Epidemiological and Environmental Health Surveillance Department, DF. Results: The male population aged $31-45$ years represented $86 \%$ of the leptospirosis cases; most belonged to the social classes D and E. Conclusions: In the DF, preventive measures should be concentrated on economically active male adults of social classes $\mathrm{C}, \mathrm{D}$, and $\mathrm{E}$ with the aim of promoting health.
\end{abstract}

Keywords: Leptospirosis. Infectious disease. Epidemiology.

Human leptospirosis affects approximately 5,000 people in Brazil annually ${ }^{1}$. Outbreaks of the disease are associated with climatic and environmental disasters (floods), but in many areas, it remains endemic ${ }^{2-4}$. Therefore, recognition of the environmental conditions influencing the risk of infection and the profile of the vulnerable human population are important for prevention and control of the disease ${ }^{5}$.

The Federal District (DF), Brazil, has a population of approximately three million people ${ }^{6}$ in a territory of $5,789 \mathrm{~km}^{2}$. The Human Development Index indicates the population of the DF as having a higher income per capita, greater and better access to education and healthcare, and a high life expectancy and quality ${ }^{1}$.

The DF is known for high temperatures and low humidity for most of the year. The rainfall season is concentrated between October and March, with occasional intense precipitations that can cause flooding ${ }^{7}$. Although these environmental and social conditions are not always favorable for the occurrence of leptospirosis in humans, the disease rates in the DF are worrying ${ }^{1}$.

Human leptospirosis is endemic to the region, with the epidemiological profile practically unknown in the $\mathrm{DF}^{1,8}$. This lack of information hampers health surveillance, planning of

Corresponding author: Dr. Márcio Botelho de Castro.

e-mail: mbcastro@unb.br

Received 8 May 2017

Accepted 15 December 2017 preventive measures, and effective control of the disease. This study aims to clarify the social and economic characteristics of human leptospirosis cases in the DF, thereby providing tools for the promotion of public health policies.

This socio-epidemiological characterization of autochthonous human cases of leptospirosis in the DF, Brazil, covers cases between 2011 and 2015. It was carried out based on the information from the databases of the Epidemiological and Environmental Health Surveillance Department of the Federal District, part of the Ministry of Health ${ }^{1}$, and data from the Brazilian Institute of Geography and Statistics [Instituto Brasileiro de Geografia e Estatística (IBGE)] $]^{8}$

The cases were confirmed using parameters set by the World Health Organization and the Ministry of Health for human leptospirosis according to clinical, epidemiological, and laboratory criteria9. Their autochthony was defined by epidemiological and environmental research carried out by the Health Surveillance Departments of the DF. Cases of patients residing in the DF with no probable infection place (PIP) were declared indefinite and were excluded from the study.

The variables collected from each patient in the databases were sex (male or female); age; socioeconomic class A, B, C, D, and $\mathrm{E}$ according to family mean income by IBGE parameters ${ }^{6}$; probable place of infection (domicile, work, leisure, or public); and occupation or profession.

The age of the patients was divided into six groups: 0 to 10,11 to 17,18 to 30,31 to 45,46 to 60 , and over 61 years. The professional activities or occupation of the patients were 
grouped by similarity of activities and exposure to risks. The data of the collected variables were submitted to analysis of frequencies by Fisher's exact test and the Pearson correlation test. Graphpad Prism 6.01 ® software was used for drawing figures.

In the DF, during the five years analyzed, 79 autochthonous human cases of leptospirosis were registered, with epidemiological and environmental investigations and confirmation of PIP. Of the total number of patients, $86.1 \%$ were male and $13.9 \%$ female. The age groups (Figure 1A) with the highest number of leptospirosis cases were 31 to 45 years and 46 to 60 years; however, there were no differences between majority of the age groups $(\rho>0.05)$, except for patients in the age group of 0 to 10 years $(\rho<0.0001)$.

Workplace and home (Figure 1B) were identified as the main sites of infection $(\rho<0.0001)$ compared to leisure and public places. There was no significant difference between acquiring the disease at home or during work activity $(\rho=0.3359)$.

Social class A presented the lowest rate of leptospirosis infection during the analyzed period (Figure 1C) compared to the other social strata $(\rho<0.0001)$. The disease was distributed similarly between classes B and C $(\rho=0.1497)$ and between
$\mathrm{C}$ and $\mathrm{D} / \mathrm{E}(\rho=0.0723)$, and it was higher in the $\mathrm{D} / \mathrm{E}$ stratum than in class $B(\rho=0.0014)$.

The frequency of leptospirosis infection was not different among individuals with different occupations or professional activities in the population (Figure 1D), except among students and retirees $(\rho=0.0467)$. In the DF, $46 \%$ of all cases studied occurred among retailers, drivers, security guards, civil construction workers, and general helpers.

Leptospirosis is considered a neglected disease due to the absence of targeted public health policies, and it affects more than one million people per year, worldwide ${ }^{10-12}$. In recent years, the number of human cases that deserve attention in the DF has varied ${ }^{1}$. The data point to a lack of prevention and control strategies when considering the environment of disease development and, especially, the profile of the population affected $^{11}$. Recognition of the socio-professional profile of the patients presents a way to promote health among the most vulnerable populations ${ }^{13,14}$.

The population affected by the disease in the DF between 2011 and 2015 was predominantly male. The data corroborate the national profile established by the Brazilian Ministry of Health $^{1}$ and other countries in Latin America and Africa ${ }^{10,12}$.
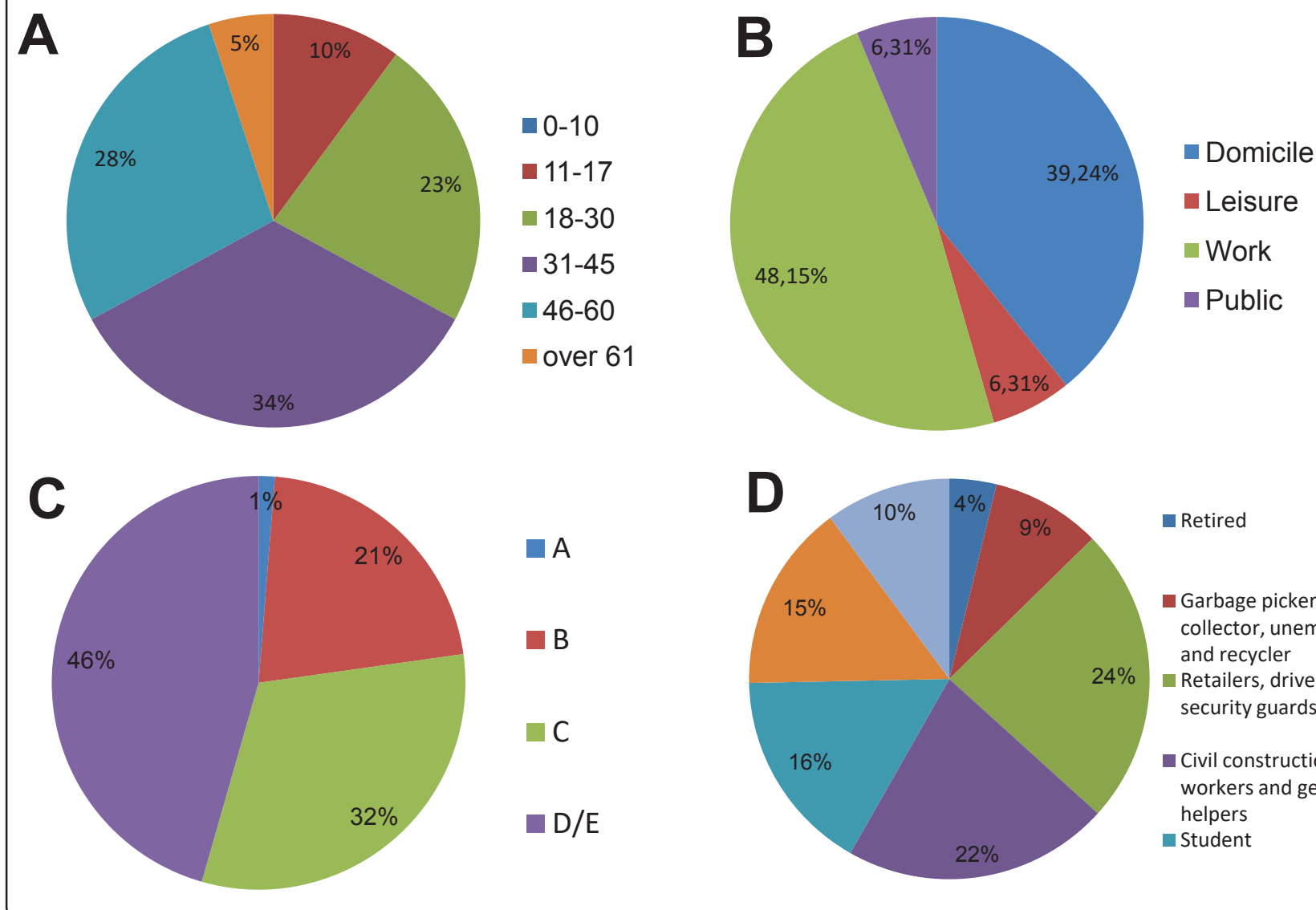

Retired

- Garbage picker, garbage collector, unemployed and recycler Retailers, drivers and security guards

Civil construction workers and general helpers Student

FIGURE 1: Human leptospirosis in the Federal District, 2011-2015. A. Age groups (years) of patients. B. Probable places of infection of autochthonous cases. C. Socioeconomic classes affected by the disease. D. Professional activities or occupations of the patients grouped by similarity of activities and exposure to risks. 
Because leptospirosis is a disease related to risky work and climatic and environmental disasters ${ }^{11}$, the male population is considered more vulnerable due to increased exposure and reduced attention to preventive care ${ }^{12}$.

Regarding the age of patients in the DF, the economically active population, consisting of individuals between 18 and 60 years of age, represented $85 \%$ of cases. This study also confirmed that individuals aged between 31 and 45 years were the most vulnerable. DF data are aligned with that of other Brazilian regions ${ }^{13,14}$. Studies of the social cost of human leptospirosis in areas with disease outbreaks have already indicated that the male population older than 18 years of is vulnerable ${ }^{13,14}$.

The results of the research by age group also point to other poorly understood aspects regarding leptospirosis infection. There were no case records in the population aged 0 to 10 years and few case records were identified in the elderly population. These two age extremes of the population require studies and follow-up to understand the chain of exposure, infection, and disease development, not only in the DF. Moreover, these two age groups are not without risk of exposure. In areas of lower social development in the DF, it is common for children under ten years of age to play in muddy flood water, yet no record of the disease exists in this age group ${ }^{8}$.

Regarding the probable place of infection for the 79 cases of this study, most of the cases were infected in the work environment, followed by the home. The analysis of this variable does not mirror the national profile of the disease but points to peculiarities of the $\mathrm{DF}^{3,4,15}$.

The majority of DF infections appeared to have occurred during the exercise of occupational duties. Studies on the occupational character of leptospirosis have been carried out in several Brazilian regions and point to neglected risk situations, either by individuals or by employers ${ }^{15}$. Lower productivity due to infection and possible loss of life warrant investment in occupational health and worker awareness regarding the proper use of personal protective equipment ${ }^{12,15}$.

As for infections acquired at home, the DF profile is again distinct from the national profile. In Brazil, the population vulnerable to the disease usually resides on the outskirts of cities cohabiting with synanthropic rodents or in areas with unsatisfactory environmental and sanitary aspects that experience recurrent floods ${ }^{2,4,12}$. In the DF, flood conditions for individuals with PIP at home were insignificant. From the environmental reports of each case, it was hypothesized that the population is exposed to synanthropic rodents, Rattus norvegicus, as a result of repairs to the underground sewage network located in the residential environment ${ }^{8}$.

Leisure environments and public roads were also localities of human leptospirosis infection in the DF, albeit at a lower frequency. Streams and lakes have been identified as sources of infection through fishing, bathing, and swimming. In other countries, infection acquired in leisure environments is insignificant ${ }^{12}$. For infections that occurred on public roads in the DF, patients themselves reported situations inherent to the rainy season, such as flooding and overflow of sewage ${ }^{8}$.
Analyses of the economic profiles of cases of leptospirosis in the DF during the five-year study period indicated that social classes $\mathrm{D}$ and $\mathrm{E}$ were the most vulnerable. Considering the infected population with an average family income equal to or less than five minimum wages (classes C, D, and E), the proportion increased to $78 \%$ of the cases. In the DF, the vulnerable population is economically distant from the wealthy population, which is similar to other Brazilian regions and other countries ${ }^{12}$. Despite the absence of studies that directly relate average wage income to the disease, economic vulnerability is considered the most important risk factor for the disease rather than social vulnerability ${ }^{4,11}$.

The economic profile of infected patients is aligned with the general notion that the low-income population does not have sufficient access to information about prevention. Furthermore, they are usually subjected to occupational activities of greater risk and lower privilege, and they reside in areas with poor sanitation that are favorable for daily or sporadic infection ${ }^{3,4,11}$.

Regarding the professional activities and occupations of the study subjects, the results in the DF are in agreement with the activity and occupation risks indicated by the Brazilian Ministry of Health ${ }^{1}$. Strikingly, the DF contains a greater percentage of professionals such as merchants, drivers, and sellers than workers in rural areas and professionals in public cleaning services and civil construction. Activities that comprise direct contact with water, moist soil, and residues could increase exposure to infection. Hence, while performing their professional activities, individuals should be aware of the risks and take preventive measures ${ }^{15}$.

This survey of the socioeconomic characteristics of the population affected by leptospirosis in the DF between 2011 and 2015 intends to provide support for a change in the current situation and the public policies, mainly regarding disease prevention. Owing to the socioeconomic characteristics of human leptospirosis in the DF and its neglected importance in the face of the limited available information, measures should be concentrated on economically active male adults of social classes $\mathrm{C}, \mathrm{D}$, and $\mathrm{E}$ with the aim of promoting health.

\section{Acknowledgments}

The authors acknowledge the Subsecretaria de Vigilância em Saúde, Secretaria de Estado de Saúde do Distrito Federal, Brasília for technical support.

\section{Conflict of interest}

The authors declare that there is no conflict of interest.

\section{REFERENCES}

1. Ministério da Saúde (MS). Secretaria de Vigilância em Saúde. Indicadores e Dados Básicos para a Saúde. Brasília: MS; 2016. Atualizado em 21 de setembro de 2016; citado em 7 de dezembro de 2016. Available from: http://portalsaude.saude.gov.br/index.php/ situacao-epidemiologica-dados/

2. Lima RJS, Abreu EMN, Ramos FLP, Santos RD, Santos DD, Santos FAA, et al. Análise da distribuição espaço-temporal da leptospirose 
humana em Belém, Estado do Pará, Brasil. Rev Panamaz Saude. 2012;3(2):33-40.

3. Pelissari DM, Maia-Elkhoury ANS, Arsky MLN, Nunes ML. Revisão sistemática dos fatores associados à leptospirose no Brasil, 2000-2009. Epidemiol Serv Saude. 2011;20(4):565-74.

4. Vasconcelos CH, Fonseca FR, Lise MLZ, Arsky MLNS. Fatores ambientais e socioeconômicos relacionados à distribuição de casos de leptospirose no Estado de Pernambuco, Brasil, 2001-2009. Cad Saude Colet. 2012;20(1):49-56.

5. Souza VMM, Brant JL, Arsky MLS, Araújo WN. Avaliação do Sistema Nacional de Vigilância Epidemiológica da Leptospirose Brasil, 2007. Cad Saude Colet. 2010;18(1):95-105.

6. Instituto Brasileiro de Geografia e Estatística (IBGE). Censo demográfico 2010. Dados por unidade federada. Rio de Janeiro: IBGE; 2011. Atualizado em 12 de agosto de 2012; citado em 7 de dezembro de 2016. Disponível em: http://www.ibge.gov.br/ estadosat/perfil.php?sigla $=\mathrm{df}$

7. Instituto Nacional de Meteorologia (INMET). Banco de Dados Meteorológicos para Ensino e Pesquisa. Brasília DF: Normas Climatológicas; 2016. Atualizado em 5 de abril de 2016; citado em 7 de dezembro de 2016. Disponível em: http://www.inmet.gov.br/ portal/

8. Secretaria de Estado de Saúde do Distrito Federal. Subsecretaria de Vigilância em Saúde. Dados sobre leptospirose humana das Diretorias Epidemiológica e de Vigilância Ambiental em Saúde 2015. Boletim Epidemiológico Interno. Brasília: SES-DF; 2015. 15p.
9. Albuquerque Filho APL, Araújo JG, Souza IQ, Martins LC, Oliveira MI, Silva MJB, et al. Validation of a case definition for leptospirosis diagnosis in patients with acute severe febrile disease admitted in reference hospitals at the state of Pernambuco, Brazil. Rev Soc Bras Med Trop. 2011;44(6):735-9.

10. Allan KJ, Biggs HM, Halliday JEB, Kazwala RR, Maro VP, Cleaveland S, et al. Epidemiology of leptospirosis in Africa: a systematic review of a neglected zoonosis and a paradigm for 'one health' in Africa. PLoS Negl Trop Dis. 2015;9(9):e-0003899.

11. Araújo WN, Brooke F, Ribeiro GS, Reis RB, Felzemburgh RDM, Reis MG, et al. Knowledge, attitudes, and practices related to leptospirosis among Urban Slum Residents in Brazil. Am J Trop Med Hyg. 2013;88(2):359-63.

12. Bello S, Rodríguez M, Paredes A, Mendivelso F, Walteros D, Rodríguez F, et al. Comportamiento de la vigilancia epidemiológica de la leptospirosis humana en Colombia, 2007-2011. Biomedica. 2013;33(1):153-60.

13. Costa E, Costa YA, Lopes AA, Sacramento E, Bina JC. Severe forms of leptospirosis: clinical, demographic and environmental aspects. Rev Soc Bras Med Trop. 2001;34(3):261-7.

14. Romero EC, Bernardo CC da M, Yasuda PH. Human leptospirosis: a twenty-nine-year serological study in São Paulo, Brazil. Rev Inst Med Trop São Paulo. 2003;45(5):245-8.

15. Clazer M, Rodrigues GV, Araújo L, Lopes KFC, Zaniolo MM, Gerbasi ARV, et al. Leptospirose e seu aspecto ocupacional: revisão de literatura. Arq Cienc Vet Zool. 2015;18(3):191-8. 